\title{
Dinâmica fermentativa e microbiológica de silagens dos capins tanzânia e marandu acrescidas de polpa cítrica peletizada
}

\author{
Rogério Marchiori Coan ${ }^{1}$, Ricardo Andrade Reis ${ }^{2}$, Gisela Rojas Garcia ${ }^{3}$, Ruben Pablo Schocken- \\ Iturrino $^{3}$, Daniel de Souza Ferreira ${ }^{4}$, Flávio Dutra de Resende ${ }^{5}$, Felipe do Amaral Gurgel ${ }^{6}$ \\ 1 Zootecnista - Doutor em Produção Animal pela UNESP - Campus de Jaboticabal \\ 2 UNESP - Campus de Jaboticabal. Bolsistas do CNPq \\ 3 Programa de Pós-Graduação em Microbiologia Agropecuária da UNESP - Campus de Jaboticabal. \\ 4 Programa de Pós-Graduação em Zootecnia da UNESP - Campus de Jaboticabal. \\ ${ }^{5}$ Apta - Agência Paulista de Tecnologia dos Agronegócios/Colina - SP. \\ ${ }^{6}$ Graduando em Zootecnia da UNESP/Campus de Botucatu - SP.
}

RESUMO - O experimento foi conduzido com o objetivo de avaliar a dinâmica fermentativa e microbiológica de silagens de capins tropicais acrescidas de polpa cítrica. Os capins tanzânia (Panicum maximum cv. Tanzânia) e marandu (Brachiaria brizantha (Hochst ex. A. Rich) Stapf cv. Marandu) foram colhidos aos 64 e 49 dias de rebrota, respectivamente, e ensilados com 0,5 ou $10 \%$ de polpa cítrica peletizada (PCP), em relação à matéria verde, durante 1, 4, 7, 14, 21, 28 e 56 dias. Foram utilizados silos experimentais de PVC adaptados com válvula do tipo Bunsen para eliminação dos gases. A forragem foi compactada visando obter densidade de $550 \mathrm{~kg} / \mathrm{m}^{3}$. O delineamento utilizado foi o inteiramente ao acaso com três repetições, em esquema de parcelas subdivididas. A inclusão de PCP aumentou os teores de MS e diminuiu o pH das silagens. A adição de

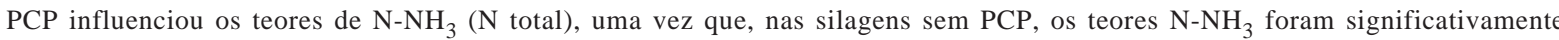
elevados, o que as caracteriza como de qualidade duvidosa. A adição de PCP aumentou a concentração molar dos ácidos acético e propiônico. A população de enterobactérias foi detectada somente no primeiro dia de fermentação nas silagens do capimtanzânia e até o 18o dia nas do capim-marandu. Nas silagens avaliadas, a população de bactérias homofermentativas foi semelhante à das bactérias heterofermentativas.

Palavras-chave: ácidos orgânicos, aditivos, bactérias, clostrídeos, pH

\section{Microbiological and fermentative dynamics of tanzaniagrass and marandugrass silage using pelleted citrus pulp as an additive}

\begin{abstract}
The experiment was carried out to evaluate the fermentative and microbiological dynamics of the tropical grass silages using pelleted citrus pulp (PCP) as an additive. The Tanzania (Panicum maximum cv. Tanzania) and Marandu (Brachiaria brizantha (Hochst. ex. A. RICH) Stapf cv. Marandu) grasses were harvested at 64 and 49 days of regrowth, respectively. The following treatments were evaluated: control (0\%), addition of $5 \%$ and $10 \%$ of pelleted citrus pulp (PCP) in a fresh matter basis, and seven fermentation periods (1, 4, 7, 14, 21, 28, and 56 days) after the ensilage. Experimental PVC silos with Bunsen valve to eliminate gas were used. The forage was compacted to obtain $550 \mathrm{~kg} / \mathrm{m}^{3}$ of bulk density. It was used a split-plot arrangement in a complete randomized experimental design, with three replications per treatment. The addition of PCP increased the DM concentration and reduced the $\mathrm{pH}$ values of the silages. The concentration of $\mathrm{NH}_{3}-\mathrm{N}$ (total $\mathrm{N}$ ) was affected by the PCP addition, and the absence of PCP resulted in silages with high $\mathrm{N}$-ammonia concentration, which characterizes silages with questionable quality. The addition of PCP increased the molar concentration of the acetic and propionic acids. The enterobacteria population was detected only in the first day in the tanzaniagrass silage, and until the tenth eighth day of fermentation on the marandugrass silage. The homofermentative bacteria population was similar to the heterofermentative on the evaluated silages.
\end{abstract}

Key Words: additives, bacteria, clostridium, organic acids, $\mathrm{pH}$

\section{Introdução}

Na alimentação de bovinos, a substituição das tradicionais silagens de milho e de sorgo pelas de capim tem despertado maior interesse de técnicos e de pecuaristas por ser uma forma de armazenamento da forragem que permite a preservação de quase todo o seu valor nutritivo.

Gramíneas forrageiras tropicais, principalmente as dos gêneros Brachiaria e Panicum têm sido utilizadas em sistemas de manejo intensivo e promovido resultados 
animadores. Entretanto, quando ensiladas em estádio de desenvolvimento vegetativo precoce, essas plantas apresentam elevada qualidade nutricional, mas possuem baixo teor de MS, elevado poder tampão (PT) e baixos teores de carboidratos solúveis (CS). Esses fatores interferem no processo fermentativo, impedindo a rápida redução do $\mathrm{pH}$ e possibilitando o desenvolvimento de fermentações indesejáveis (Woolford, 1984; Woolford, 1990).

Woolford (1984) relata que os teores de MS e CS e a capacidade tampão são fatores importantes sobre o potencial de ensilagem de uma planta forrageira. Esse autor sugeriu que os teores de MS devem ser no mínimo de $25 \%$ e que a relação entre carboidratos solúveis e a capacidade tampão deve ser inferior a 3,0 para possibilitar a obtenção de silagem de qualidade satisfatória. Quanto aos carboidratos solúveis, o teor inicial mínimo necessário para garantir intensa fermentação lática, de acordo com Woolford (1984), seria de 6 a 8\% na MS, enquanto Johnson et al. (1966) estabeleceram como mínimo o teor de 15\% na MS da forragem.

De acordo com Playne \& McDonald (1966), 68 a 80\% do poder tampão pode ser atribuído à fração ânion da forragem, representada pelos sais de ácidos orgânicos, ortofosfatos, sulfatos, nitratos e cloretos. Entre os valores de pH, 6 e 4, somente os ânions de sais orgânicos e os ortofosfatos são tamponantes, ressaltando-se que o efeito do ortofosfato é menor e que a fração protéica apresenta impacto reduzido sobre o poder tampão.

Para o sucesso da ensilagem, é necessário garantir a fermentação lática e inibir o crescimento de microrganismos indesejáveis, como clostrídeos, enterobactérias, leveduras e fungos. O controle do desenvolvimento de clostrídeos depende da redução do $\mathrm{pH}$ e do aumento da pressão osmótica (maior teor de MS). Para as enterobactérias, que geralmente são inibidas em $\mathrm{pH}$ abaixo de 4,5, o controle é semelhante (Woolford, 1984; Stefanie et al., 2000).

Nesse sentido, realizou-se este trabalho com o objetivo de avaliar a dinâmica fermentativa e microbiológica de silagens dos capins tanzânia e marandu acrescidas ou não de polpa cítrica peletizada.

\section{Material e Métodos}

A ensilagem dos capins tanzânia (experimento 1) e marandu (experimento 2) foi realizada em períodos experimentais distintos. Ambos os experimentos foram desenvolvidos no Setor de Forragicultura e no Laboratório de Microbiologia da FCAV/UNESP, Campus de Jaboticabal, SP.

No dia 14/11/2002, a área (3,0 ha) experimental do capimtanzânia (experimento 1) foi rebaixada utilizando-se roçadeira. O material remanescente foi retirado da área e, no dia 15/11/2002, procedeu-se à fertilização da área com $60 \mathrm{~kg}$ de $\mathrm{N} / \mathrm{ha}, 15 \mathrm{~kg}$ de $\mathrm{P}_{2} \mathrm{O}_{5} /$ ha e $60 \mathrm{~kg}$ de $\mathrm{K}_{2} \mathrm{O} / \mathrm{ha}$, utilizando-se $300 \mathrm{~kg}$ do adubo fórmula 20-05-20, de acordo com recomendações de Werner et al. (1996). Após 64 dias (17/1/2003) de crescimento vegetativo, realizaram-se o corte e a colheita da forragem com máquina colhedeira de forragem, regulada para corte a $30 \mathrm{~cm}$ do solo (Rodrigues, 1986).

No dia 16/1/2003, a área (0,5 ha) experimental do capim-marandu (experimento 2) foi rebaixada utilizando-se 16 bovinos da raça Nelore com $390 \mathrm{~kg}$ de PV. No dia 17/1/2003, procedeu-se à fertilização da área com 50 kg de $\mathrm{N} / \mathrm{ha}, 12,5 \mathrm{~kg}$ de $\mathrm{P}_{2} \mathrm{O}_{5} /$ ha e $50 \mathrm{~kg}$ de $\mathrm{K}_{2} \mathrm{O} / \mathrm{ha}$, utilizando-se $250 \mathrm{~kg}$ do adubo fórmula 20-05-20, de acordo com recomendações de Werner et al. (1996). Após 49 dias (7/3/2003) de crescimento vegetativo, realizaram-se o corte e a colheita da forragem com máquina colhedeira de forragem, regulada para que o corte fosse realizado a $25 \mathrm{~cm}$ do solo (Rodrigues, 1986).

Ambas as áreas foram estabelecidas em latossolo eutrófico típico, de textura muito argilosa a moderada, caulítico-oxítico mesoférrico, de relevo suave ondulado (Andrioli \& Centurion, 1999).

No momento da ensilagem e de acordo com os períodos experimentais correspondentes (experimentos 1 e 2), os capins tanzânia e marandu apresentaram, respectivamente, 120 e $88 \mathrm{~cm}$ de altura, massa de forragem de 6,3 e 5,7 t.MS/ha; teor de MS de 27,3 e 28,1\%; porcentagem de folhas de 74,4 e $66,8 \%$ na matéria verde; e porcentagem de caule de 25,6 e 33,2\% na matéria verde.

Após a colheita nos períodos correspondentes, as forragens dos capins tanzânia (experimento 1) e marandu (experimento 2) foram ensiladas com adição de 0,5 ou $10 \%$ de polpa cítrica peletizada na matéria verde. A adição de polpa cítrica peletizada foi realizada no momento da ensilagem, efetuando-se a homogeneização das forragens colhidas com o aditivo, em recipientes com capacidade de 20 L. Como silos experimentais, foram utilizados tubos de PVC com $10 \mathrm{~cm}$ de diâmetro e $50 \mathrm{~cm}$ de altura, com tampas de PVC dotadas de anel de borracha, de forma a possibilitar a vedação adequada. Na parte superior de cada silo, foi adaptada uma válvula tipo Bunsen, visando à eliminação dos gases produzidos.

As forragens foram pesadas para determinação do volume dos tubos de PVC e compactadas por meio de bastões de ferro em camadas de aproximadamente $10 \mathrm{~cm}$ de forma a possibilitar densidade de $550 \mathrm{~kg} / \mathrm{m}^{3}$. Avaliou-se a dinâmica fermentativa e microbiológica de cada silagem nos tempos 1, 4, 7, 14, 21, 28 e 56 dias após a ensilagem. Após cada período de fermentação, os silos foram abertos e uma 
porção inicial foi descartada. O material de cada silo foi homogeneizado manualmente e dividido em três porções; a primeira foi utilizada para determinação dos teores de MS, de acordo com AOAC (1980), e de CS, conforme Johnson et al. (1966). O poder tampão foi mensurado segundo metodologia de Playne \& McDonald (1966). A segunda porção foi utilizada para determinação dos teores de nitrogênio amoniacal ( $\left.\mathrm{N}-\mathrm{NH}_{3}\right)$, segundo AOAC (1980), do pH (Silva, 1998) e da concentração molar de ácidos graxos voláteis (AGVs) em cromatógrafo líquido gasoso, conforme descrito por Palmquist \& Conrad (1971).

As análises microbiológicas, especificamente na contagem total de lactobacilos e enterobactérias, foram realizadas segundo metodologia descrita por Jonsson (1991). Para diferenciação das bactérias acidoláticas em homofermentativas e heterofermentativas, utilizou-se a metodologia descrita por McDonald et al. (1987). A presença de clostrídeos foi determinada de acordo com a metodologia de Tosi et al. (1982).

A capacidade fermentativa (CF) foi calculada de acordo com a equação proposta por Kaiser et al. (2002), CF = MS $+8 \times(\mathrm{CS} / \mathrm{CT})$; em que a MS é expressa em \%, os carboidratos solúveis (CS) em \% da MS e a capacidade tampão (CT), em e.mg de $\mathrm{HCl} / 100 \mathrm{~g}$ de $\mathrm{MS}$.

O delineamento experimental utilizado em ambos os experimentos (experimentos 1 e 2) foi o inteiramente casualizado, com três repetições de campo, empregando-se o esquema de parcelas subdivididas, de modo que os níveis de PCP corresponderam às parcelas e o tempo (dias após ensilagem), às subparcelas. Os dados foram analisados utilizando-se o programa ESTAT e aplicando-se o teste Tukey $(\mathrm{P}<0,05)$ a $5 \%$ de significância na comparação de médias entre as causas de variação.

\section{Resultados e Discussão}

Nas silagens de capim-tanzânia (experimento 1), foram determinados 27,3\% de MS, 3,2\% de CS (\% MS) e 8,0\% de PB (\% MS), poder tampão de 19,3 e.mg HCL/100 g MS e capacidade fermentativa de $28,6 \%$, enquanto, nas silagens de capim-marandu (experimento 2 ), foram obtidos, respectivamente, valores de $28,1 \%$ de MS, 2,8\% de CS (\% MS), 9,7\% de PB (\% MS), poder tampão de 18,4\% e capacidade fermentatida de $29,3 \%$.

Os teores de MS dos capins foram moderados, o que está relacionado ao elevado poder tampão (PT) e aos baixos conteúdos de CS. Entretanto, os teores de MS foram superiores e o poder tampão inferior aos verificados em gramíneas forrageiras tropicais (Bernardes, 2005; Henrique \& Bose,
1992; Castro et al., 2006). No entanto, Coan et al. (2005) observaram teores de MS e CS superiores nos capins tanzânia e mombaça aos 60 dias de crescimento vegetativo.

A capacidade fermentativa (CF) dos capins tanzânia e marandu comprovou baixo potencial de ensilabilidade desses capins, uma vez que os valores de CF foram inferiores a 35, o que, de acordo com Oude Elferink (1999), é o mínimo para obtenção de silagens láticas.

A polpa cítrica peletizada utilizada neste estudo apresentou $89,6 \%$ de MS, $19,2 \%$ de CS (\% MS) e $6,8 \%$ de PB (\% MS).

No primeiro dia de fermentação, as silagens dos capins tanzânia e marandu apresentaram aumento na população de enterobactérias em todos os níveis de PCP (Figuras 1 e 2). Nas silagens de capim-tanzânia, não foi observado desenvolvimento desses microrganismos após o quarto dia da ensilagem. Provavelmente, o pH e a ausência de oxigênio impediram o desenvolvimento desses microrganismos. Nas silagens de capim-marandu (Figura 2), verificou-se variação na população de enterobactérias e sua presença deixou de ser detectada a partir do $14^{0}$ dia da ensilagem nas silagens com 5\% de PCP e no 56 0 dia da ensilagem nas silagens com 0 e $10 \%$ de PCP. Um fator que pode ter contribuído para a sobrevivência de enterobactérias foi a maior disponibilidade de oxigênio nos silos, decorrente da formação de bolsas de ar.

A adição de PCP não influenciou a população de clostrídeos (Figuras 1 e 2) no momento da ensilagem, fato que pode estar relacionado à inexistência de esporos da bactéria no aditivo. Verificou-se ainda que a população de clostrídeos sofreu aumento significativo 24 horas após a ensilagem, principalmente nas silagens do capim-tanzânia com 5 e $10 \%$ de PCP. A adição de 5 e 10\% de PCP nas silagens de capim-marandu resultou, respectivamente, em diminuição e aumento (Figura 2) da população de clostrídeos após 24 horas da ensilagem. No decorrer do tempo, as populações de clostrídeos nas silagens, de ambos os capins, sofreram diminuição $(\mathrm{P}<0,05)$ do $1^{0}$ ao 56 음 dia da ensilagem. A partir do 560 dia, não foi observada a presença dessas bactérias nas silagens de capim-marandu.

Bernardes (2005) observou que a adição de 5 e $10 \%$ de PCP elevou a população de clostrídeos no momento da ensilagem do capim-marandu, fato atribuído pelo autor à possível contaminação do aditivo com esporos da bactéria. A população de clostrídeos observada nas silagens dos capins tanzânia e marandu foi superior às reportadas por Bernardes (2005), que encontrou 0,2 a 0,8 log ufc/g de silagem de capim-marandu com 0, 5 e 10\% de PCP.

A população de lactobacilos nas silagens dos capins tanzânia e marandu (Figuras 1 e 2) aumentou um dia após 

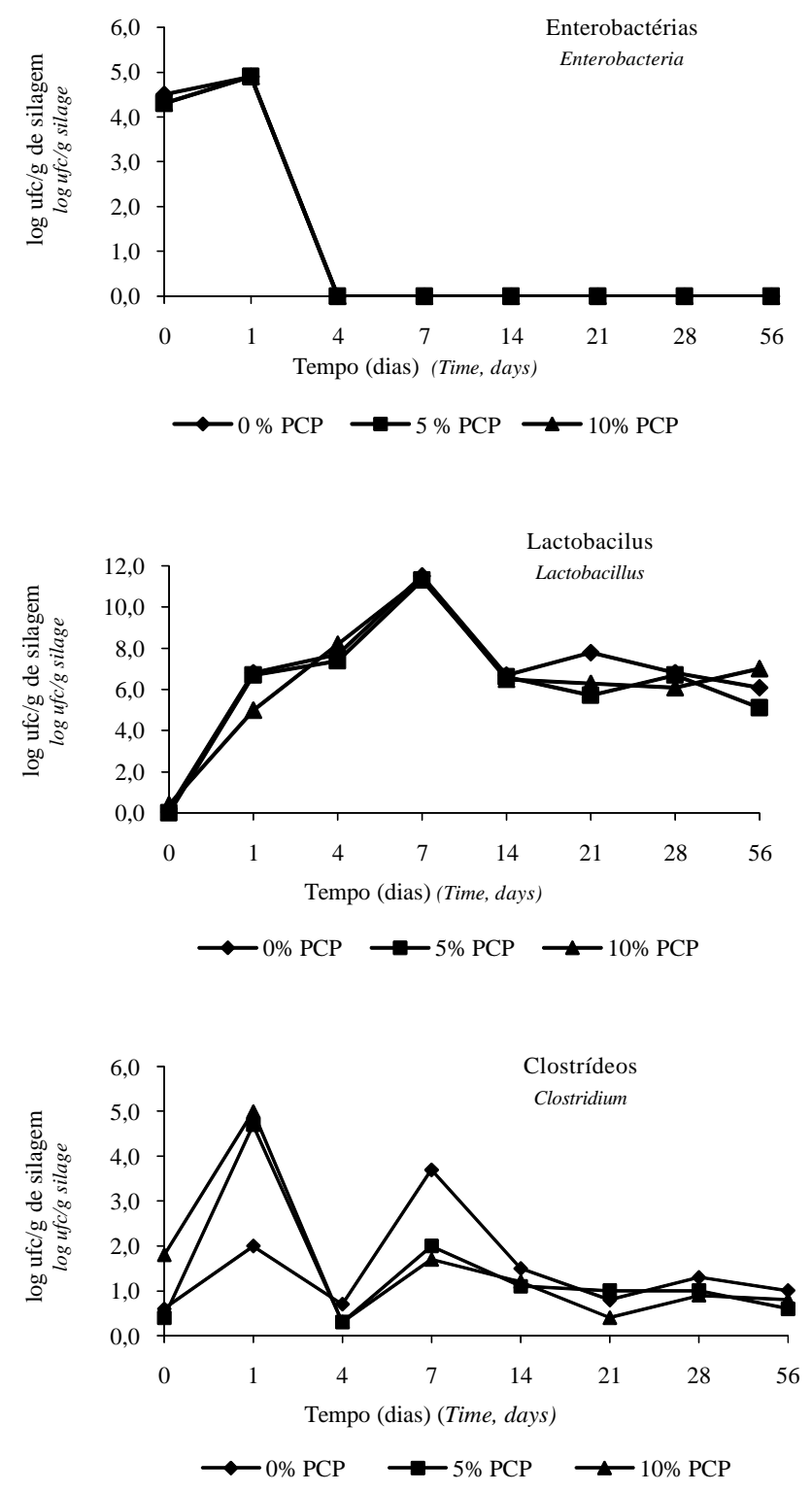

Figura 1 - Dinâmica microbiológica de silagens de capim-tanzânia acrescidas de 0,5 ou $10 \%$ de polpa cítrica peletizada (PCP) avaliada em diferentes tempos após abertura dos silos.

Figure 1 - Microbiological dynamics of tanzaniagrass silages without additive (control) and with addition of 5 and $10 \%$ of citrus pulp $(C P)$, as a function of silo opening.

ensilagem e esse aumento se estendeu até o 7ํㅜ dia após a ensilagem. Após essa fase, a população de lactobacilos permaneceu quase constante até o 56o dia da ensilagem, embora a amplitude de variação da população tenha sido perceptível no decorrer dos tempos de abertura dos silos para ambas as silagens. Esse fato pode estar relacionado à menor disponibilidade de oxigênio, condição que favorece o desenvolvimento de bactérias láticas, principalmente do gênero Lactobacillus.

Do momento que antecedeu o processo de ensilagem até o 56 으 dia de fermentação, as proporções de bactérias
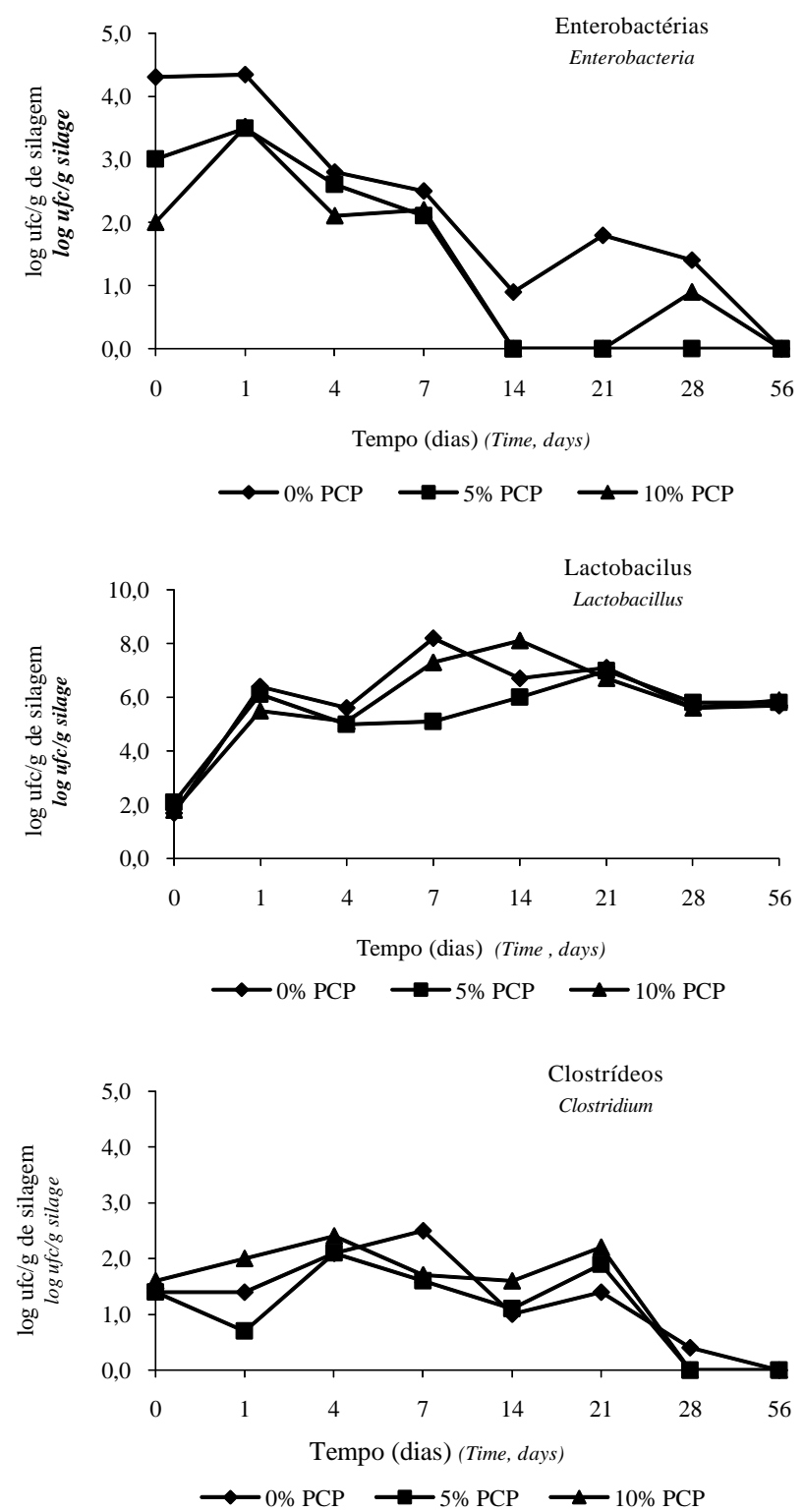

Figura 2 - Dinâmica microbiológica de silagens de capimmarandu acrescidas de 0, 5 e 10\% de polpa cítrica peletizada (PCP) avaliada em diferentes tempos após abertura dos silos.

Figure 2 - Microbiological dinamyc of marandugrass silages without additive (control) and with addition of 5 and $10 \%$ of citrus pulp $(C P)$, as a function of silo opening.

homo e heterofermentativas foram semelhantes, tanto nas silagens do capim-tanzânia como nas de capim-marandu (Figuras 3 e 4). De modo geral, 50,0; 49,0; 46,0; 51,0; 51,0 e 51,5\% das bactérias das silagens dos capins tanzânia e marandu com 0 , 5 e $10 \%$ de PCP, respectivamente, foram classificadas como homofermentativas. Os valores encontrados para as proporções dessas bactérias foram inferiores aos verificados por Bernardes (2005), que, em silagens de capim-marandu acrescidas de 0,5 e $10 \%$ de PCP, verificou que 80,60 e $70 \%$ das cepas de lactobacilos encontradas eram homofermentativas. De acordo com McDonald et al. 


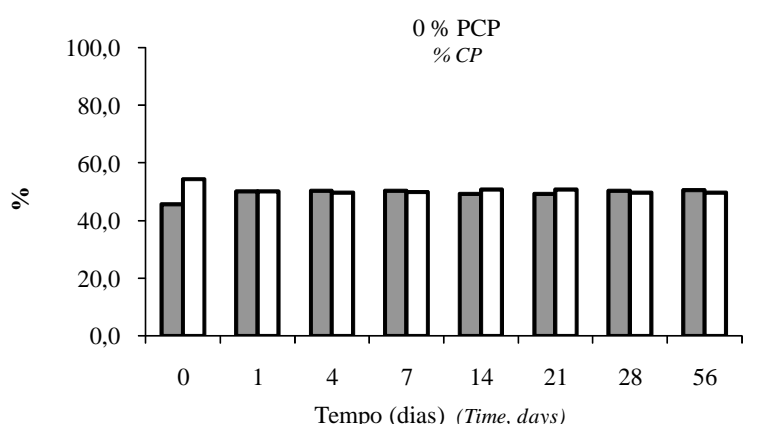

口Heterofermentativas

口Homofermentativas

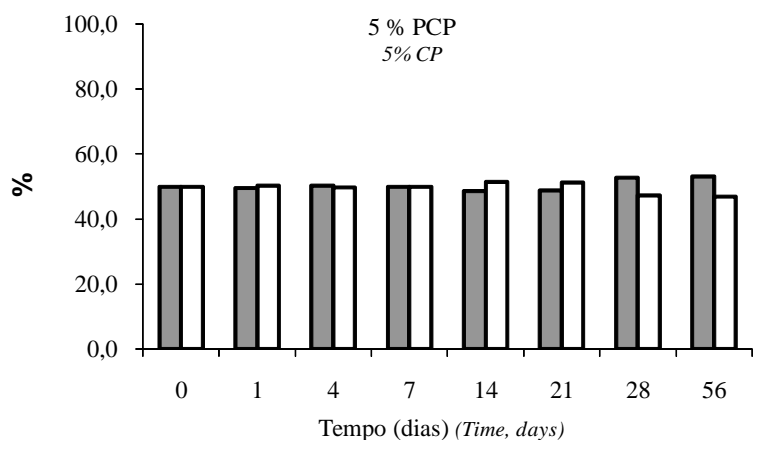

口Heterofermentativas aHomofermentativas

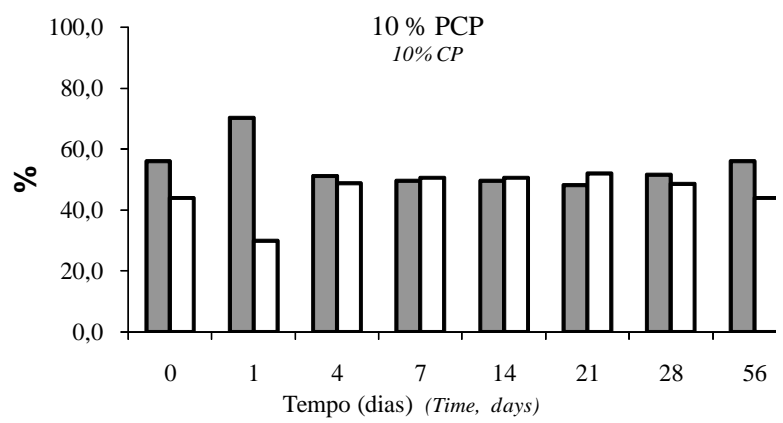

口 Heterofermentativas

口Homofermentativas

Figura 3 - Ocorrência de bactérias homo e heterofermentativas em silagens de capim-tanzânia acrescidas de 0, 5 e $10 \%$ de polpa cítrica peletizada (PCP) e avaliadas em diferentes tempos após abertura dos silos.

Figure 3 - Occurrence of homo and heterofermentative bacteria on tanzaniagrass silages without additive (control) and with addition of 5 and $10 \%$ of citrus pulp (CP), as a function of silo opening.

(1991), quando o pH da silagem atinge valor inferior a 5,0, a população de bactérias acidoláticas heterofermentativas permanece estável, em virtude da acidez inibitória ao seu crescimento, e ocorre maior atividade da população de bactérias homofermentativas, as quais são mais eficientes (produzem somente ácido-lático) e promovem redução mais rápida do $\mathrm{pH}$.

Nas silagens dos capins tanzânia e marandu, os teores de MS aumentaram de acordo com os níveis de PCP (Figuras

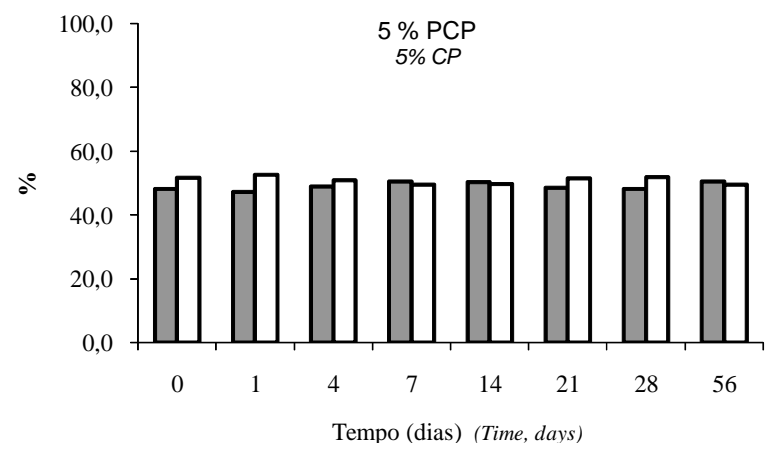

口Heterofermentativas $\mathbf{0}$ Homofermentativas

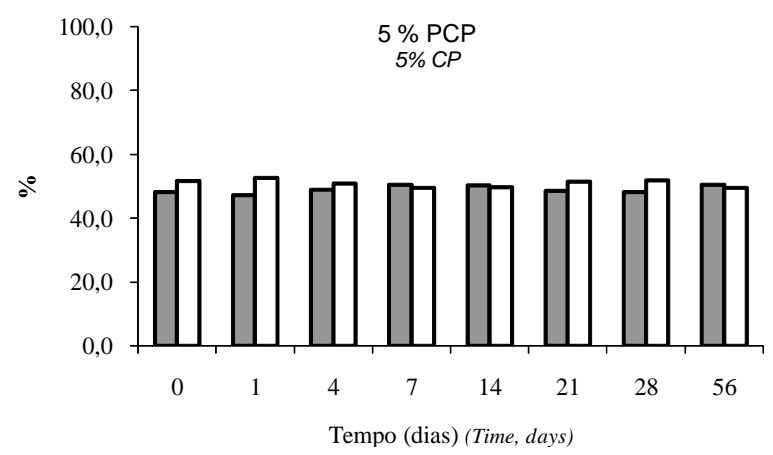

口Heterofermentativas $\mathbf{0}$ Homofermentativas

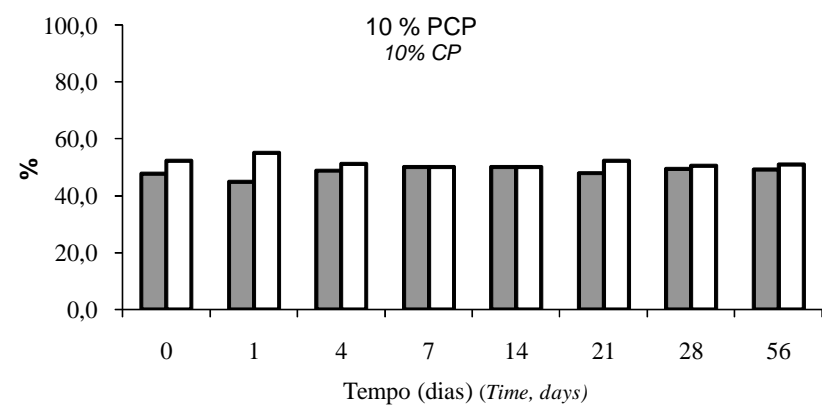

口Heterofermentativas $\mathbf{0}$ Homofermentativas

Figura 4 - Ocorrência de bactérias homo e heterofermentativas em silagens de capim-marandu acrescidas de 0, 5 e $10 \%$ de polpa cítrica peletizada (PCP) e avaliada em diferentes tempos após abertura dos silos.

Figure 4 - Occurrence of homo and heterofermentative bacteria on marandugrass silages without additive (control) and with addition of 5 and $10 \%$ of citrus pulp (CP), as a function of silo opening.

5 e 6). No decorrer do processo fermentativo, não foram observadas variações bruscas nos teores de MS, independentemente das silagens avaliadas. Esse fato pode ser explicado pela estabilidade das silagens durante o processo fermentativo e pela baixa drenagem de efluentes.

De acordo com Woolford (1984) e McDonald et al. (1991), o pH, juntamente com a concentração de ácidos orgânicos e de nitrogênio amoniacal, são parâmetros normalmente empregados na qualificação do processo de 

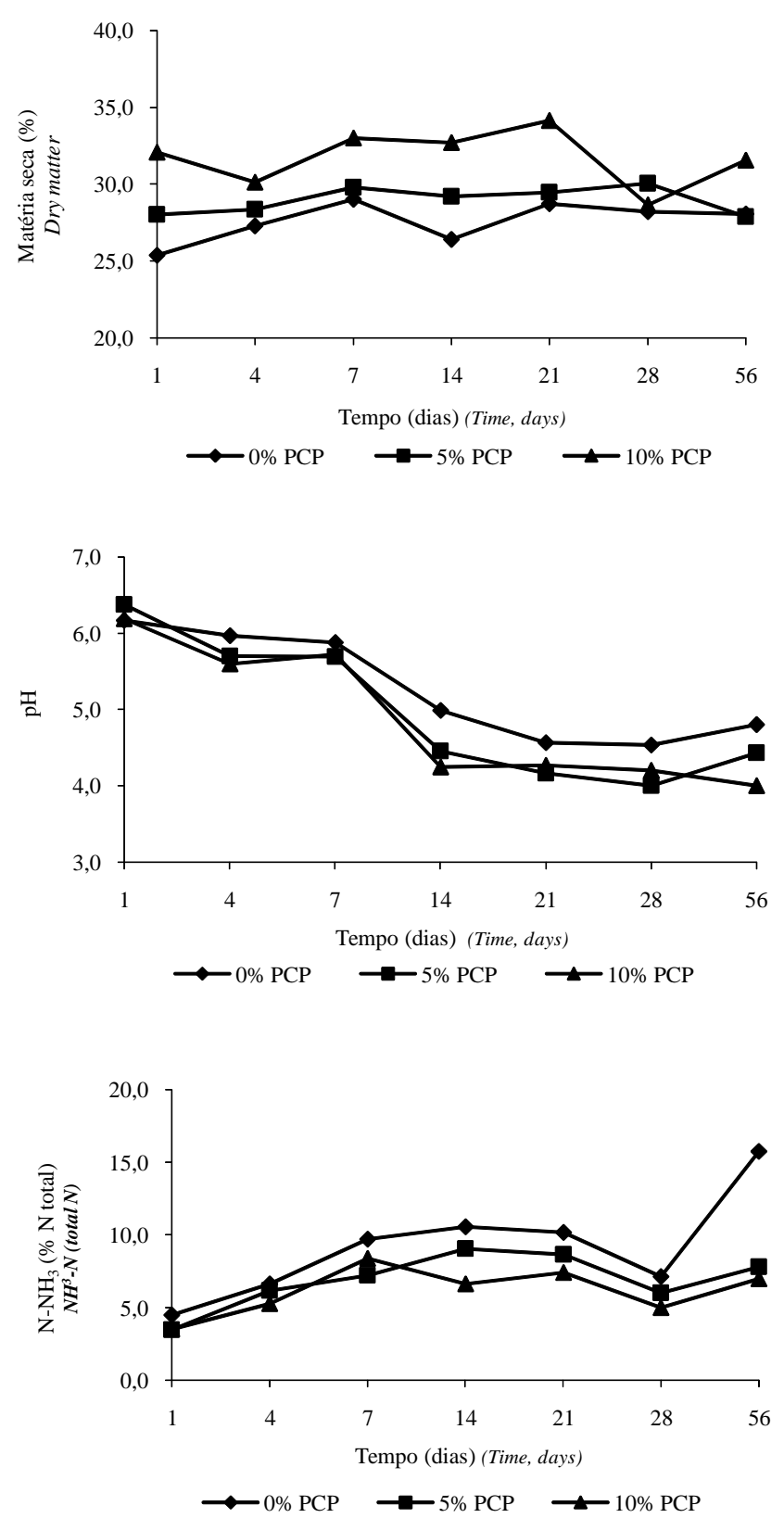

Figura 5 - Variação temporal dos teores de $\mathrm{MS}, \mathrm{pH}$ e N-NH $\mathrm{N}_{3}$ de silagens de capim-tanzânia acrescidas de 0, 5 e 10\% de polpa cítrica peletizada (PCP) e analisada em diferentes tempos após abertura dos silos.

Figure 5 - Temporal variation of $\mathrm{DM}, \mathrm{pH}$, and $\mathrm{NH}_{3}-\mathrm{N}$ in tanzaniagrass silage without additive (control) and with addition of 5 and $10 \%$ of citrus pulp (CP), as a function of silo opening.

ensilagem. Valores de pH entre 3,8 e 4,2 são esperados para uma silagem bem conservada. Os valores de $\mathrm{pH}$ (Figuras 5 e 6) das silagens dos capins tanzânia e marandu acrescidas de 5 e $10 \%$ de PCP indicam produção de ácido lático durante o processo fermentativo, uma vez que as concentrações molares dos ácidos acético, propiônico, butírico e valérico não foram suficientes para promover redução do pH para os patamares observados, uma vez
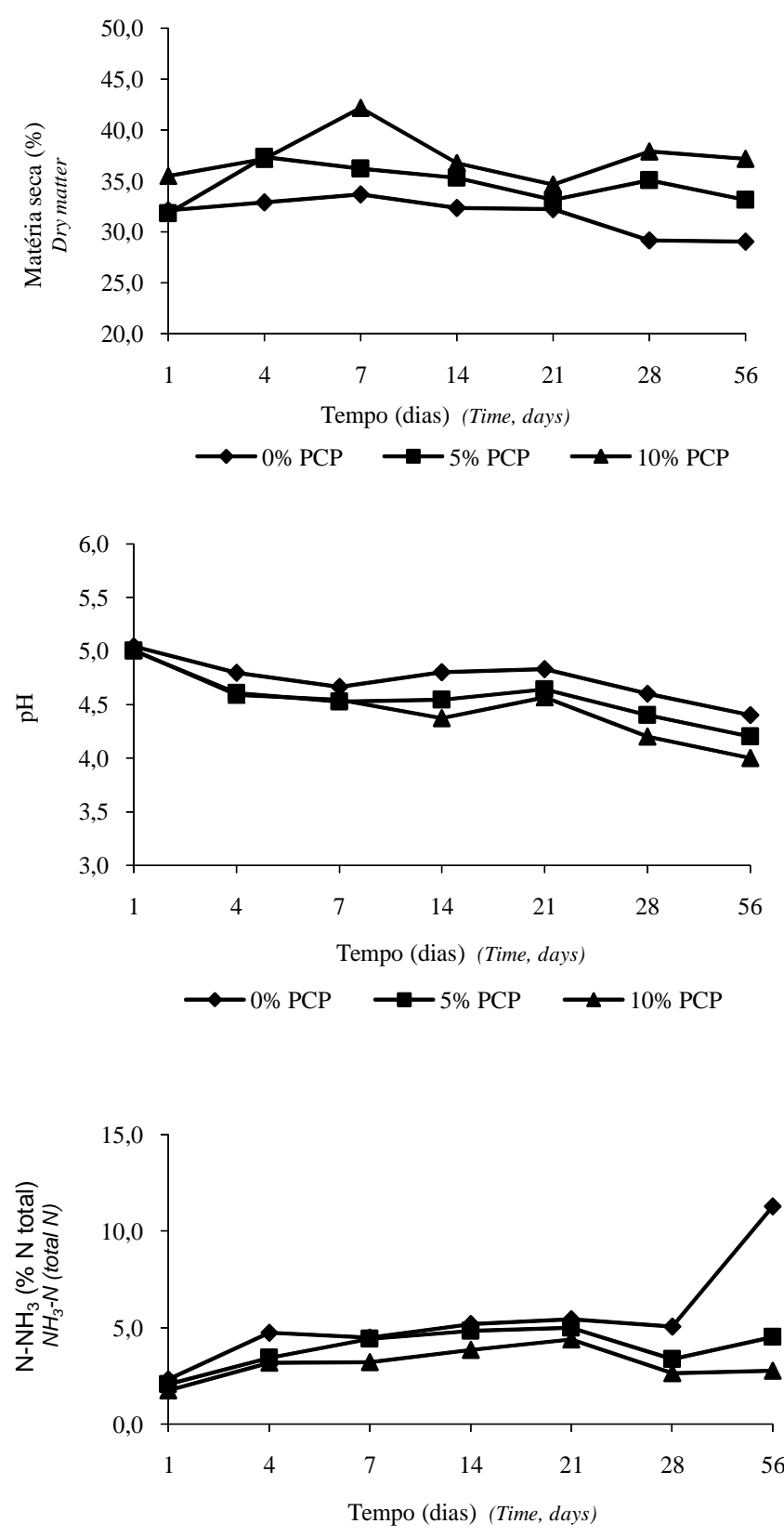

$\neg 0 \% \mathrm{PCP} \longrightarrow-5 \% \mathrm{PCP} \longrightarrow-10 \% \mathrm{PCP}$

Figura 6 - Variação temporal dos teores de $\mathrm{MS}, \mathrm{pH}$ e N-NH $\mathrm{N}_{3}$ de silagens de capim-marandu acrescidas de 0, 5 e $10 \%$ de polpa cítrica peletizada (PCP) analisada em diferentes tempos após abertura dos silos.

Figure 6 - Temporal variation of $\mathrm{DM}, \mathrm{pH}$, and $\mathrm{NH}_{3}-\mathrm{N}$ in marandugrass silage without additive (control) and with addition of 5 and $10 \%$ of citrus pulp (CP), as a function of silo opening.

que essas substâncias são classificadas como ácidos fracos.

Nas silagens dos capins tanzânia e marandu sem PCP, observaram-se valores elevados de $\mathrm{pH}$ e $\mathrm{N}-\mathrm{NH}_{3}$ (Figuras 5 e 6), que, associados à elevada concentração molar do ácido acético produzido (Figuras 7 e 8) e à elevada população de bactérias láticas heterofermentativas (Figuras 3 e 4), permitem afirmar que a qualidade fermentativa dessas silagens foi 
relativamente baixa, provavelmente em virtude do baixo perfil de nutrientes dessas silagens, condição que limitou o processo fermentativo.

De acordo com Benachio (1965), quanto ao teor de nitrogênio amoniacal (\% do nitrogênio total), as silagens são classificadas em muito boa, quando os valores são inferiores a 10\%; aceitável, quando se mantêm entre 10 e $15 \%$; e insatisfatória, quando acima de $20 \%$. De acordo com esse parâmetro, as silagens com 5 e 10\% de PCP classificaram-se como muito boas, enquanto aquelas sem PCP poderiam ser classificadas como de qualidade aceitável. A análise das Figuras 5 e 6 permite concluir que as silagens dos capins tanzânia e marandu sem PCP sofreram proteólise após o $10^{0}$ dia do início do processo fermentativo.

Woolford (1984) e McDonald et al. (1991) comentaram que a proteólise se estende durante a fermentação quando não ocorrem condições ácidas suficientes para que os microrganismos indesejáveis sejam inibidos. No entanto, as condições ácidas foram rapidamente estabelecidas, embora as faixas de $\mathrm{pH}$ obtidas para as silagens dos capins tanzânia $(4,5)$ e marandu $(4,6)$ sem adição de PCP não tenham sido suficientes $(3,2)$ para inibir a atividade proteolítica dos microrganismos.

De acordo com Pahlow et al. (2003), a produção de amônia pode ter sido conseqüência do baixo perfil de carboidratos fermentáveis presentes nas silagens sem adição de PCP, uma vez que as bactérias acidoláticas podem utilizar aminoácidos como fonte primária de energia para crescimento e metabolismo. Esses autores comentaram que essas bactérias não são proteolíticas, porém, comportam-se dessa forma quando o aporte de nutrientes é baixo e/ou quando ocorre baixo poder de síntese de aminoácidos, tornando-se necessário nessas circunstâncias suprimento extra de nutrientes.

No entanto, o pH não deve ser utilizado como critério exclusivo na avaliação da fermentação, pois seu efeito inibidor de microrganismos depende da velocidade de declínio da concentração iônica e do teor de umidade do material ensilado.

O aumento no nível de PCP promoveu declínio $(\mathrm{P}<0,05)$ nos valores de $\mathrm{pH}$ das silagens dos capins tanzânia e marandu (Figuras 5 e 6). Verificou-se redução brusca do pH
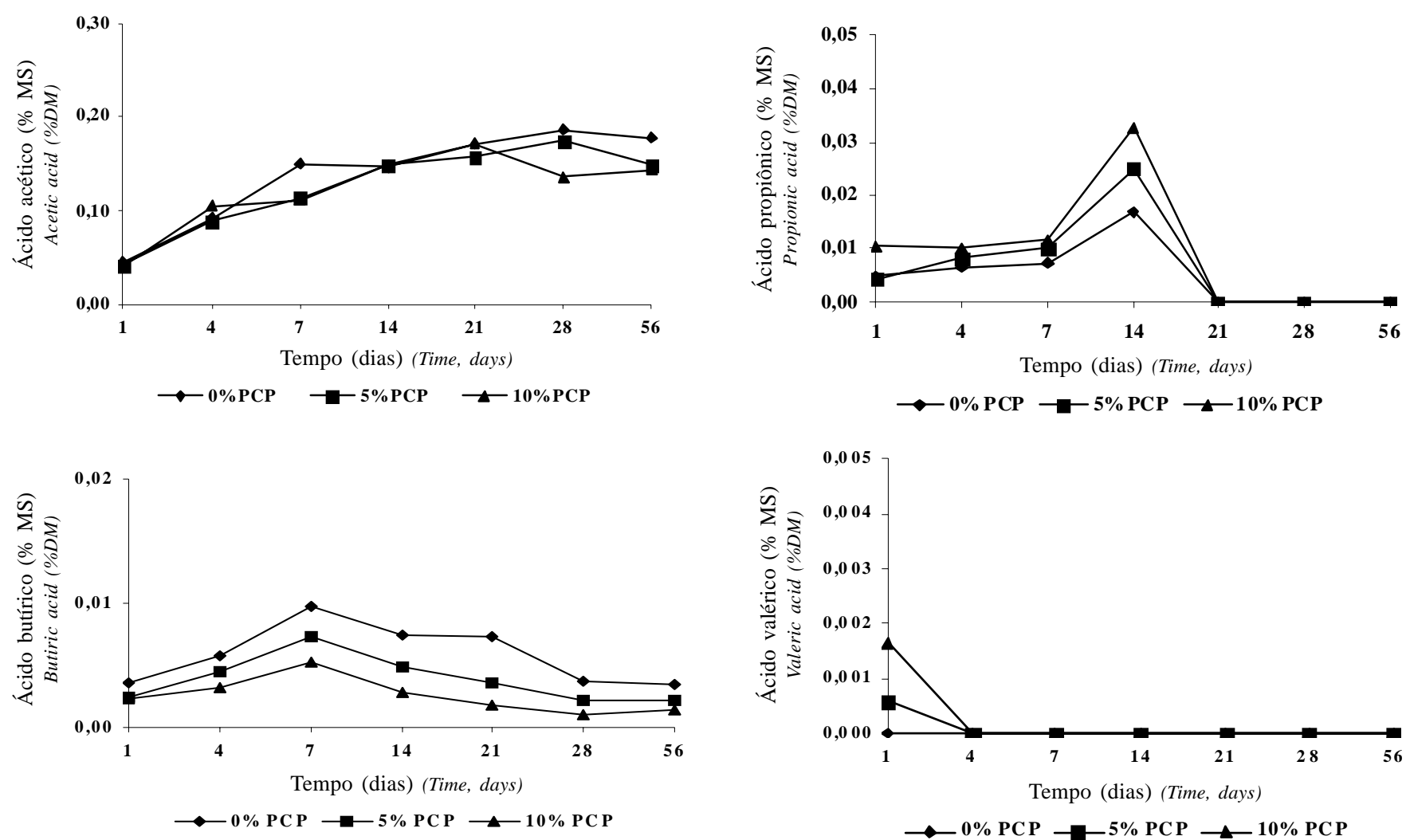

Figura 7 - Variação temporal das concentrações molares dos ácidos acético, propiônico, butírico e valérico em silagens de capimtanzânia acrescidas de 0, 5 e 10\% de polpa cítrica peletizada (PCP) avaliada em diferentes tempos após abertura dos silos.

Figure 7 - Temporal variation of molar concentration in acetic, propionic, butyric, and valeric acids in tanzaniagrass silages without additive (control) and with addition of $5 \%$ and $10 \%$ of citrus pulp (CP), as a function of silo opening. 

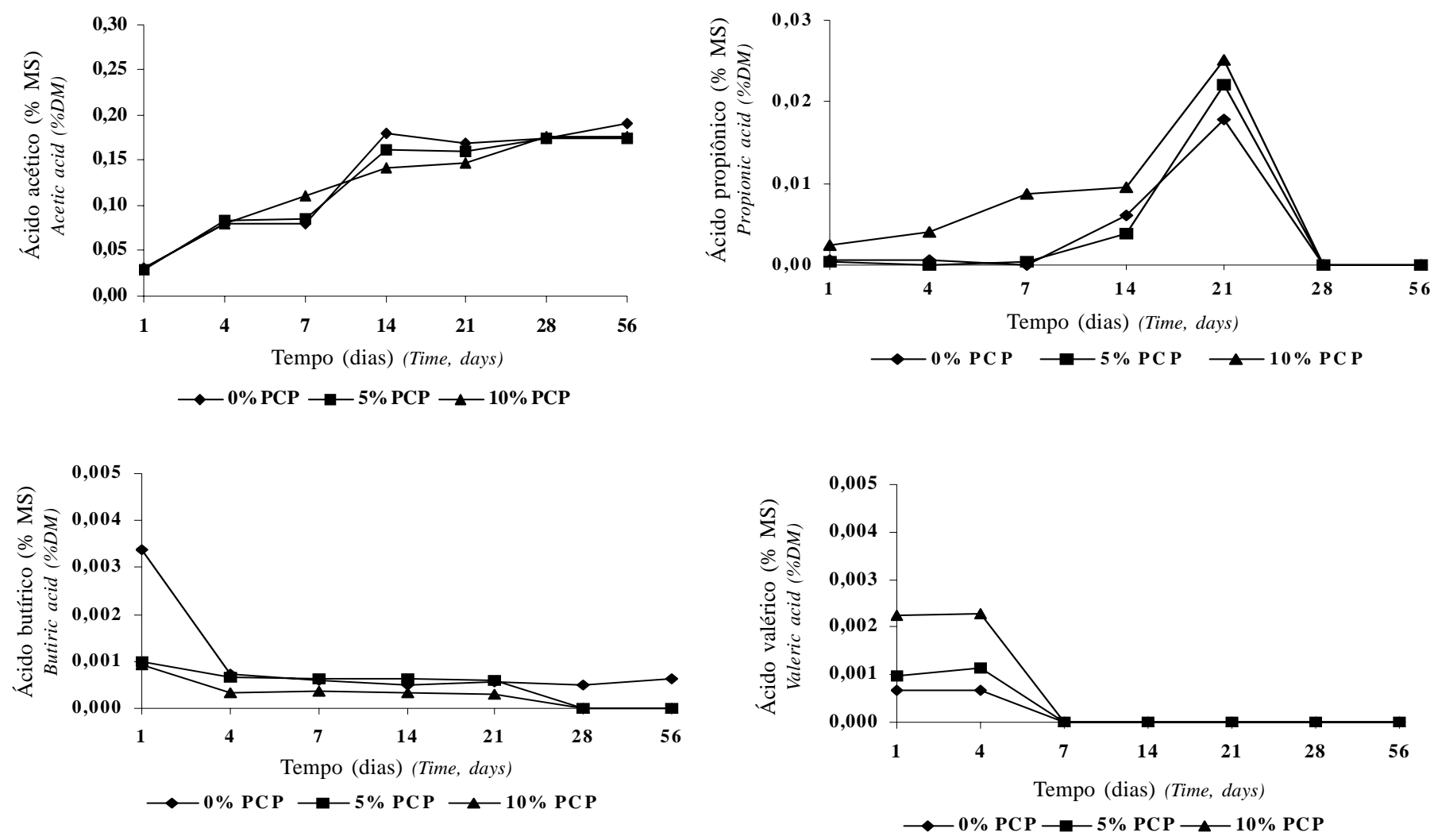

Figura 8 - Variação temporal das concentrações molares dos ácidos acético, propiônico, butírico e valérico em silagens de capimmarandu acrescidas de 0,5 e $10 \%$ de polpa cítrica peletizada (PCP) e avaliadas em diferentes tempos após abertura dos silos.

Figure 8 - Temporal variation of molar concentration in acetic, propionic, butyric, and valeric acids in marandugrass silages, without additive (control) and with addition of 5 and $10 \%$ of citrus pulp (CP), as a function of silo opening.

do $1^{\mathrm{o}}$ ao $4^{\mathrm{o}}$ dia $(\mathrm{P}<0,05)$, no entanto, partir desse dia, o decrécimo foi mais lento. Nas silagens do capim-tanzânia, a partir do $21^{\underline{0}}$ dia, houve estabilização do pH. Nas silagens do capim-marandu (Figura 6), os valores de $\mathrm{pH}$ decresceram lentamente até o último dia de abertura dos silos (56 dias). $\mathrm{O}$ pH de estabilização das silagens de capim-tanzânia foi 4,6; 4,2 e 4,2 e do capim-marandu, 4,4; 4,2 e 4,0 nas silagens com 0,5 e $10 \%$ de PCP, respectivamente. Os dados encontrados neste estudo estão de acordo com os obtidos por Bernardes (2005), que trabalhou com os níveis de 5 e $10 \%$ de PCP na ensilagem do capim-marandu com 58 dias de idade e obteve $\mathrm{pH}$ de 4,5, 4,2 e 4,0.

Iturrino (2005) estudou o efeito da inclusão de diferentes níveis (0, 3, 6, 9 e 12\%) de PCP nos valores de pH de silagens de capim-tifton 85 e observou que, a partir do $60^{\circ}$ dia da ensilagem, houve estabilização do $\mathrm{pH}$ em todos os níveis de PCP avaliados. A polpa cítrica, em decorrência do elevado potencial absorvente e por disponibilizar carboidratos fermentescíveis às bactérias acidoláticas, contribui para redução do $\mathrm{pH}$ e melhor conservação das silagens acrescidas desse aditivo.
A inclusão de PCP promoveu diminuição significativa nos teores de $\mathrm{N}-\mathrm{NH}_{3}$ (\% $\mathrm{N}$ total) em ambas as silagens (Figuras 5 e 6). Entretanto, com o avançar do período de fermentação, os teores de $\mathrm{N}-\mathrm{NH}_{3}$ dessas silagens aumentaram $(\mathrm{P}<0,05)$ até o $21^{\mathrm{o}}$ dia, provavelmente em virtude da atividade de enterobactérias, que promoveram a proteólise da massa ensilada. Os resultados obtidos neste estudo estão de acordo com os descritos por Igarasi (2002), que avaliou as silagens de capim-tanzânia com 15\% de PCP e constatou que a adição de PCP elevou os teores de MS e reduziu os valores de $\mathrm{N}-\mathrm{NH}_{3}$.

Em virtude de problemas na calibração do cromatógrafo líquido gasoso, os teores de ácido lático não foram determinados nas silagens. A presença de PCP diminuiu a concentração de ácido acético a partir do 4 o dia da ensilagem e manteve-se nessa condição até o 56으 dia, tanto para as silagens do capim-tanzânia quanto para as do capimmarandu.

A produção de ácido acético aumentou no decorrer do tempo, o que está relacionado à elevada atividade microbiológica das bactérias heterofermentativas (Figuras 
3 e 4) durante todo o processo fermentativo das silagens avaliadas. Os teores de ácido acético nas silagens dos capins tanzânia e marandu estão abaixo do nível crítico, de 0,8\% (\% MS). Níveis de ácido acético superiores indicam alterações indesejáveis durante o processo de ensilagem (Mahanna, 1997).

De acordo com McDonald et al. (1991), a elevada produção de ácido acético é indício da atuação de enterobactérias durante os estádios iniciais da fermentação da silagem, competindo por nutrientes com as bactérias láticas. Essa condição não foi observada nas silagens de capim-tanzânia, uma vez que não foi detectado crescimento de enterobactérias após o 4 o dia da ensilagem (Figura 1). As silagens de capim-marandu apresentaram significativa população de enterobactérias no decorrer do processo fermentativo (Figura 2) e provavelmente contribuíram para a maior produção de ácido acético para estas silagens.

A maior concentração de ácido propiônico foi observada nas silagens dos capins tanzânia e marandu acrescidas de PCP, principalmente no nível de 10\% (Figuras 7 e 8). Ao longo do período, houve aumento $(\mathrm{P}<0,05)$ na concentração de ácido propiônico no $14^{\circ}$ e no $21^{\circ}$ dia, porém, não foi detectada produção deste ácido após o 21ํㅡ e o 28o dia para as silagens dos capim tanzânia e marandu, respectivamente. Esse fato pode ser esclarecido se considerado o início da fase anaeróbica do processo fermentativo, quando as bactérias acidoláticas iniciam sua atividade, produzindo ácidos orgânicos.

As silagens dos capins tanzânia e marandu acrescidas de PCP apresentaram menores concentrações de ácido butírico (Figuras 7 e 8) ao longo de todo o processo fermentativo. Nas silagens de capim-marandu com 5 e 10\% de PCP, não foi detectada produção de ácido butírico após o 28oㅡ dia, o que está de acordo com os dados apresentados nas Figuras 1 e 2, que comprovam atividade limitada de clostrídeos nestas silagens, provavelmente em razão dos baixos valores de pH observados (Figuras 5 e 6). Segundo Muck (1988), a atividade dessas bactérias diminui acentuadamente em silagens com alto teor de MS, enquanto, em forragens com alta umidade, os clostrídeos podem tolerar altas concentrações de ácidos e íons $\mathrm{H}^{+}$, sendo necessário $\mathrm{pH}$ mais baixo para conservar a silagem em torno de 3,2.

A adição de PCP aumentou a concentração molar do ácido valérico logo após a ensilagem dos capins tanzânia e marandu (Figuras 7 e 8). Entretanto, ao longo do tempo, observou-se que, após o $4^{\circ}$ e o $7^{0} \underline{0}$ dia da ensilagem, não foram detectadas produções desse ácido nessas silagens.

\section{Conclusões}

A adição de polpa cítrica peletizada promoveu aumento nos teores de MS e reduziu os valores de $\mathrm{pH}$ e de nitrogênio amoniacal de silagens dos capins tanzânia e marandu. Os baixos valores de $\mathrm{pH}$ observados diminuíram a incidência de enterobactérias e clostrídeos nas silagens. As concentrações dos ácidos orgânicos foram significativamente influenciadas pela adição de polpa cítrica peletizada e proporcionaram maiores teores de ácido acético e propiônico. Recomenda-se a adição de polpa cítrica peletizada, na proporção de $10 \%$ da matéria verde da forragem, para garantir adequado processo fermentativo das silagens.

\section{Literatura Citada}

ANDRIOLI, I.; CENTURION, J.F. Levantamento detalhado dos solos da Faculdade de Ciências Agrárias e Veterinárias de Jaboticabal. In: CONGRESO BRASILEIRO DE CIÊNCIA DO SOLO, 27., 1999, Brasília. Anais... Brasília: Sociedade Brasileira de Ciência do Solo, 1999. (CD-ROM).

ASSOCIATION OF OFFICIAL AGRICULTURAL CHEMIST AOAC. Official methods of analyses of the Association of Official analytical chemists. 11.ed. Washington, D.C. 1980. 1015p.

BENACHIO, S. Niveles de melaza en silo experimental de milho criollo (Sorghum vulgare). Agronomia Tropical, v.14, n.4, p.651-658, 1965.

BERNARDES, T.F.; REIS, R.A.; MOREIRA, A.L. Fermentative and microbiological profile of marandugrass ensiled with citrus pulp pellets. Scientia Agricola, v.62, p.214-220, 2005.

CASTRO, F.G.; NUSSIO, L.G.; HADDAD, C.M. et al. Características de fermentação e composição químico-bromatológica de silagens de capim-Tifton 85 confeccionadas com cinco teores de matéria seca. Revista Brasileira de Zootecnia, v.35, n.2, p.1-14, 2006.

COAN, R.M.; VIEIRA, P.F.; SILVEIRA, R.N. et al. Inoculante enzimático-bacteriano, composição química e parâmetros fermentativos das silagens dos capins tanzânia e mombaça. Revista Brasileira de Zootecnia, v.34, n.2, p.416-424, 2005

HENRIQUE, W.; BOSE, M.L.V. Efeitos de aditivos enzimáticosbacterianos sobre a qualidade da silagem do capim elefante (Pennisetum purpureum Schum.). Revista da Sociedade Brasileira de Zootecnia, v.21, n.3, p.429-438, 1992.

IGARASI, M.S.; NUSSIO, L.G.; PAZZIANI, S.F. et al. Losses of grass Tanzania (Panicum maximum) affect by matter level and particle size. In: INTERNACIONAL SILAGE CONFERENCE, 13., 2002, Auchincruive. Proceedings... Auchincruive: 2002. p.64-65.

ITURRINO, R.P.S.; REIS, R.A.; COAN, R.M. et al. Alterações químicas e microbiológicas nas silagens de capim-Tifton 85 após a abertura dos silos. Revista Brasileira de Zootecnia, v.34, n.2, p.464-471, 2005.

JOHNSON, R.R.; BALWANI, T.L.; JOHNSON, L.J. et al. Corn plant maturity. II. Effect on in vitro cellulose digestibility and soluble carbohydrate content. Journal of Animal Science, v.25, p.617-623, 1966.

JONSSON, A. Growth of clostridium tyrobutyricum during fermentation and aerobic deterioration of grass silage. Journal Science Food and Agriculture, v.54, p.557-568, 1991. 
KAISER, E.; WEIB, K.; POLIP, L.V. A new concept for the estimation of the ensiling potential of forages. In: THE INTERNATIONAL SILAGE CONFERENCE, 13., 2002, Auchincruive. Proceedings... Auchincruive: 2002. p.344-358.

MAHANNA, B. [1997]. Troubleshooting silage problems. Disponível em: http:/www.pioneer.com/xweb. Acesso em: 14/7/2006.

McDONALD, L.C.; McFEETERS, R.F.; DAESCHEL, M.A. et al. A differential medium for the enumeration of homofermentative and heterofermentative lactic acid bacteria. Applied Environmental Microbiology, v.53, n.6, p.1382-1384, 1987.

McDONALD, P.; HERDERSON, A.R.; HERON, S.J.E. Biochemistry of silage. 2.ed. Marlow: Chalcombe Publication, 1991. 340p.

MUCK, R.E. Factors influencing silage quality and they implications for management. Journal of Dairy Science, v.71, n.11, p.2992-3002, 1988.

OUDE ELFERINK, S.J.W.H.; DRIEHUIS, F.; KROONEMAN, J. et al. Lactobacillus buchneri can improve the aerobic stability of silage via a novel fermentation pathway: the anaerobic degradation of lactic acid to acetic acid and 1,2-propanediol. In: INTERNATIONAL SILAGE CONFERENCE, 12., 1999, Uppsala. Proceedings... Uppsala: Swedish University of Agricultural Sciences, 1999. p.266-267.

PAHLOW, G.; MUCK, R.; DRIEHUIS, F. et al. Microbiology of ensiling. In: BUXTON, D.R.; MUCK, R.E.; HARRISON, J.H. (Eds.) Silage science and technology. Madison: ASA, CSSA, SSSA, 2003. p.31-93.

PALMQUIST, D.L.; CONRAD, H.R. Origin plasma fatty acids in lactating cows fed high grain fat diets. Journal of Dairy Science, v.54, p.1025-1033, 1971.
PLAYNE, M.J.; McDONALD, P. The buffering constituints of herbage and of silage. Journal Science Food and Agriculture, v.17, n.2, p.264-268, 1966.

RODRIGUES, L.R.A. Espécies forrageiras para pastagens: gramíneas. In: SIMPÓSIO SOBRE MANEJO DE PASTAGENS, 8., 1986, Piracicaba. Anais... Piracicaba: Fundação de Estudos Agrários Luis de Queiroz, 1986. p.375-387.

SILVA, D.J. Análises de alimentos: métodos químicos e biológicos. 2.ed. Viçosa, MG: Universidade Federal de Viçosa, 1998. 166p.

STEFANIE, J.W.H.; ELFEINK, O.; DRIEHUIS, F. et al. Silage fermentation process and their manipulation. In: FAO ELETRONIC CONFERENCE ON TROPICAL SILAGE, Rome, 1999, Rome. Proceedings... Rome: FAO, 2000. p.17-30.

TOSI, H.; SCHOCKEN-ITURRINO, R.P.; RAVAZI, J.P. Presença de Clostridium em silagem de miho colhido em diferentes estágios de desenvolvimento. Pesquisa Agropecuária Brasileira, v.17, p.1133-1136, 1982.

WERNER, J.C.; PAULINO, V.T.P.; CANTARELLA, H. et al. Recomendações de adubação e calagem para o estado de São Paulo. 2.ed. Campinas: Instituto Agronômico \& Fundação IAC, 1996. p.263-273. (Boletim Técnico, 100).

WOOLFORD, M.K. The silage fermentation. New York: Marcel Dekker, 1984. 305p.

WOOLFORD, M.K. The detrimental effects of air on silage. Journal Applied Bacteriology, v.68, p.101-116, 1990.

Recebido: 24/11/2005 Aprovado: 9/4/2007 